\title{
Chemical characterization of some substituted hydroxyapatites
}

Doreya Mohamed Ibrahim', Amany A Mostafa ${ }^{2,3}$ and Sara Ibrahim Korowash²,3*

\begin{abstract}
Synthetic multi-substituted hydroxyapatite nano powders containing silicon and or carbonate prepared by a wet chemical method. The process parameters are set up to allow the simultaneous substitution of carbonate and silicon ions in the place of phosphorus. The chemical and structural characterizations of the prepared powders are determined with the aid of; XRF, ICP, XRD and FTIR. The results show that, the ion substitution in the crystal lattice of HA caused a change in the unit cell dimensions and affected the degree of crystallization of the produced powders. The apatite formation abilityy of the prepared discs from the synthesized powders is determined by immersing in SBF solution for different periods. The degree of ion release was determined in the obtained solutions. The examined surface of the immersed discs under SEM and analyzed by CDS showed a more dense HA layer than those of un-substituted ones. The HA with the substituted silicon and carbonate ions, showed the highest solubility with greater rate of ion release, compared with carbonate-free powder. All prepared powders took sodium ion from the SBF solution during immersion, which was not recorded before.
\end{abstract}

\section{Introduction}

The calcium apatite phase forming the main mineral part of bones and teeth [1], contains several ions in different amounts substituting calcium and phosphorus in the HA lattice $[2,3]$. Whereas, the synthesized hydroxyapatite $\left(\mathrm{Ca}_{10}\left(\mathrm{PO}_{4}\right)_{6}(\mathrm{OH})_{2}, \mathrm{HA}\right)$ is a pure phase that is well established bone replacement material in orthopaedics and dentistry. These substitutions provoke changes in the HA surface structure and charge, raising its solubility and increasing the ability of synthetic HA to be involved in a natural bone remodeling process. The type and the amount of ionic substitution in the apatite phase of bone varies from $\sim 2-8 \mathrm{wt} \%$ in $\mathrm{CO}_{3}$ to minor concentrations in $\mathrm{Mg}, \mathrm{Na}$, to the ppm level for trace elements $\mathrm{Si}, \mathrm{Sr}, \mathrm{Zn}, \mathrm{Pb}$. Although these levels of substitutions are small, it is established that these elements are associated with the properties of biological apatites and play a major role in the biochemistry of bone, enamel and dentin [4-6].

Hydroxyapatite contains carbonate ions substituting both the phosphate (B-type CHA) and hydroxyl (Atype-CHA) sites of the HA structure. The B-type is the

\footnotetext{
* Correspondence: rose_a2222@yahoo.com

Biomaterials Department, National Research Centre, 12622 Dokki, Cairo,

Egypt

Full list of author information is available at the end of the article
}

preferential carbonate substitution found in the bone of a variety of species, with the $\mathrm{A} / \mathrm{B}$ type ratio in the range 0.7-0.9 [7]. A higher value of the A/B ratio is observed in old tissue, compared to young tissue. The presence of $\mathrm{B}$-carbonate in the apatite lattice is responsible for the decrease in its degree of crystallinity increasing thereby its solubility [8].

The importance of silicon on bone formation and calcification is tackled by different workers in vitro and in vivo studies: Carlisle et al. demonstrated the important role played by $\mathrm{Si}$ in connective tissue metabolism, especially in bone and cartilage [9]. Where, it is essential to the growth and development of biological tissue such as bone, teeth and some invertebrate skeletons. They also reported that, a reduction in $\mathrm{Si}$ in bone results in a decrease in the number of osteoblasts [10], osseomatriceal collagen, and glycosaminoglycans [11].

The addition of Si during the HA synthesis leads to an improvement of the bioactive behavior: in vitro studies by Gibson et al. demonstrated that the substitution of silicate ions for phosphate ions into hydroxyapatite enhances osteoblast cell activity, compared to phase pure HA. Silicate ion substitution is also reported to enhance the formation of a poorly crystalline surface apatite layer on HA, incubated in simulated body fluid (SBF) [12]. Furthermore, an in vivo study by Patel et al., 
comparing the rates of bone apposition to $\mathrm{HA}$ and silicon-substituted HA (Si-HA) ceramic implants demonstrated bone apposition to be significantly greater at the surface of Si-HA implants [13]. Porter et al. indicated more rapid remodeling of bone surrounding the Si-HA when compared to HA [14]. It is suggested that these findings are related to increased dissolution rates of the Si-HA implants compared to HA [15].

The present work aims to prepare different substituted hydroxyapatites, $\mathrm{Si}-\mathrm{HA}$ and $\mathrm{Si}-\mathrm{CHA}$, as well as stoichiometric pure HA powders by wet chemical method. The ability of the prepared powders to form new apatite is tested through reaction with SBF solution.

\section{Materials and methods}

\section{Sample preparation}

The pure and ion-substituted hydroxyapatites are prepared according to the method described by Jarcho et al. [16]. but with slight modification. The starting materials are $\mathrm{Ca}\left(\mathrm{NO}_{3}\right)_{2} \cdot 4 \mathrm{H}_{2} \mathrm{O}$, (VWR international Ltd.) $\left(\mathrm{NH}_{4}\right)_{2} \mathrm{HPO}_{4}$, (Mallinckrodt Inc.), $\mathrm{Si}\left(\mathrm{OCH}_{2} \mathrm{CH}_{3}\right)_{4} \mathrm{TEOS}$, (Merck), and $\mathrm{NaHCO}_{3}$, (S.d. fine-CHEM Ltd.); with the molar concentrations listed in Table 1. The procedure followed is in the flow chart (Figure 1). The different additives are added under continuous stirring at room temperature and pH 11 [Korowash S: Preparation of Bio-Hybrid Scaffolds for Tissue Engineering, unpublished]. Precipitates obtained are left to digest under a reflux at $60-65^{\circ} \mathrm{C}$ followed by leaving to age at room temperature overnight. The resulting precipitates are washed with distilled water, centrifuged followed by drying and grinding. Additionally, a sample of the as-prepared (green) powders is heated at $900^{\circ} \mathrm{C}$ for $1 \mathrm{~h}$.

The chemical constitution of the prepared powders is determined by XRF and ICP utilizing the following equipments; (AXIOS,WD-XF Sequential Spectrometer) and (ICP-OES), respectively. The molar ratio of Calcium to phosphorus as well as the concentration of the added elements, were calculated from the results obtained. The phase composition is determined by XRD utilizing an equipment by Philips operated at $40 \mathrm{KV}$ and $40 \mathrm{~mA}$ using $\mathrm{Cu} \mathrm{K} \alpha$ radiation. Scanning is carried out over the range from $2 \Theta=4^{\circ}$ to $80^{\circ}$. The Scherrer formula is used to calculate the average crystallite size. The different elemental constitutional groups are determined by
FTIR utilizing a (FT/IR-6100typeA, JASCO) equipment in the range between 400 to $4000 \mathrm{~cm}^{-1}$.

\section{Apatite formation ability}

The prepared green powders are processed in the form of discs under a pressure of $10 \mathrm{KN}$ with the following dimensions; diameter $12 \mathrm{~mm}$, height $2 \mathrm{~mm}$. Part of the prepared powders are fired at $900^{\circ} \mathrm{C}$ for $1 \mathrm{~h}$. Both green and fired discs are immersed in SBF solution for different periods; $24 \mathrm{~h}$ and, 2, 3, 5, 9, 14, 21 and 29 days, at $37^{\circ} \mathrm{C}$.

The concentration of the different constituting elements of the SBF solution (mM) is as follows: $\mathrm{Na}^{+}$ 142.0; $\mathrm{K}^{+} 5.0 ; \mathrm{Ca}^{2+} 2.5 ; \mathrm{Mg}^{2+} 1.5 ; \mathrm{Cl}^{-} 147.8 ; \mathrm{HCO}_{3}{ }^{-}$4.2; $\mathrm{HPO}_{4}{ }^{2-} 1.0 ; \mathrm{SO}_{4}{ }^{2-} 0.5$ [17]. The samples are removed out after the immersion period studied and the solutions are analyzed using spectrophotometer (UV-2401 PC, UV-VIS Recording spectrophotometer, Shimadzu, Japan) as well as with biochemical kits (Techo Diagnostic, USA) to detect the total calcium ions $\left(\mathrm{Ca}^{2+}\right)$ at $\lambda=570$ $\mathrm{nm}$ and phosphorus ions $\left(\mathrm{P}^{5+}\right)$ at $\lambda=675 \mathrm{~nm}$. The solutions are tested for other ions such as sodium $\left(\mathrm{Na}^{+}\right)$and silicon $\left(\mathrm{Si}^{4+}\right)$, using flame atomic absorption spectrometer (Varian SpectrAA). Moreover, the $\mathrm{pH}$ of the SBF is measured using a pH meter (Fisher Scientific, Pittsburgh PA). SEM, Model Philips XL 30 attached with energy dispersive X-ray spectroscope (EDS) unit, utilizing an accelerating voltage of $30 \mathrm{KV}$ to scan the surface of the discs after immersion and to determine the proportion of the surface elements.

\section{Results}

Chemical constitution of Prepared Powders as determined by XRF and ICP

The results of the chemical analysis by XRF of the different apatite powders are listed in Tables 2 and 3. The starting (calculated) and actual (measured) degree of atomic substitution in terms of molar ratios, and the related calcium/phosphorus $(\mathrm{Ca} / \mathrm{P})$ molar ratios are compared. $\mathrm{X}_{\mathrm{Si}}$ indicate the molar ratio silicon/phosphorus $(\mathrm{Si} / \mathrm{P})$. The calculated and measured molar ratios of Calcium/(phosphorus + silicon), $\mathrm{Ca} /(\mathrm{P}+\mathrm{Si})$ are also compared.

Chemical analysis carried out by ICP on the green powders of different hydroxyapatite samples confirms

Table 1 Mole proportion of the different constituents in the prepared phases

\begin{tabular}{|c|c|c|c|c|c|c|c|}
\hline \multirow[t]{2}{*}{ Sample code } & \multicolumn{4}{|c|}{ Mole concentration of constituents } & \multirow[t]{2}{*}{$\mathrm{Ca} / \mathrm{P}$ ratio } & \multirow[t]{2}{*}{ mole\% Si to P- ion substituted HA } & \multirow[t]{2}{*}{ mole\% Si to P- $\mathrm{HA}_{\mathrm{s}}$} \\
\hline & $\mathrm{Ca}$ & $\mathbf{P}$ & Si & $\mathrm{CO}_{3}$ & & & \\
\hline $\mathrm{HA}_{\mathrm{s}}$ & 0.1 & 0.06 & - & - & 1.67 & - - & - \\
\hline Si-HA & 0.1 & 0.0585 & 0.03 & - & 1.71 & 51.28 & 50 \\
\hline $\mathrm{Si}-\mathrm{CHA}$ & 0.096 & 0.0509 & 0.0031 & 0.006 & 1.88 & 6.09 & 5.167 \\
\hline
\end{tabular}




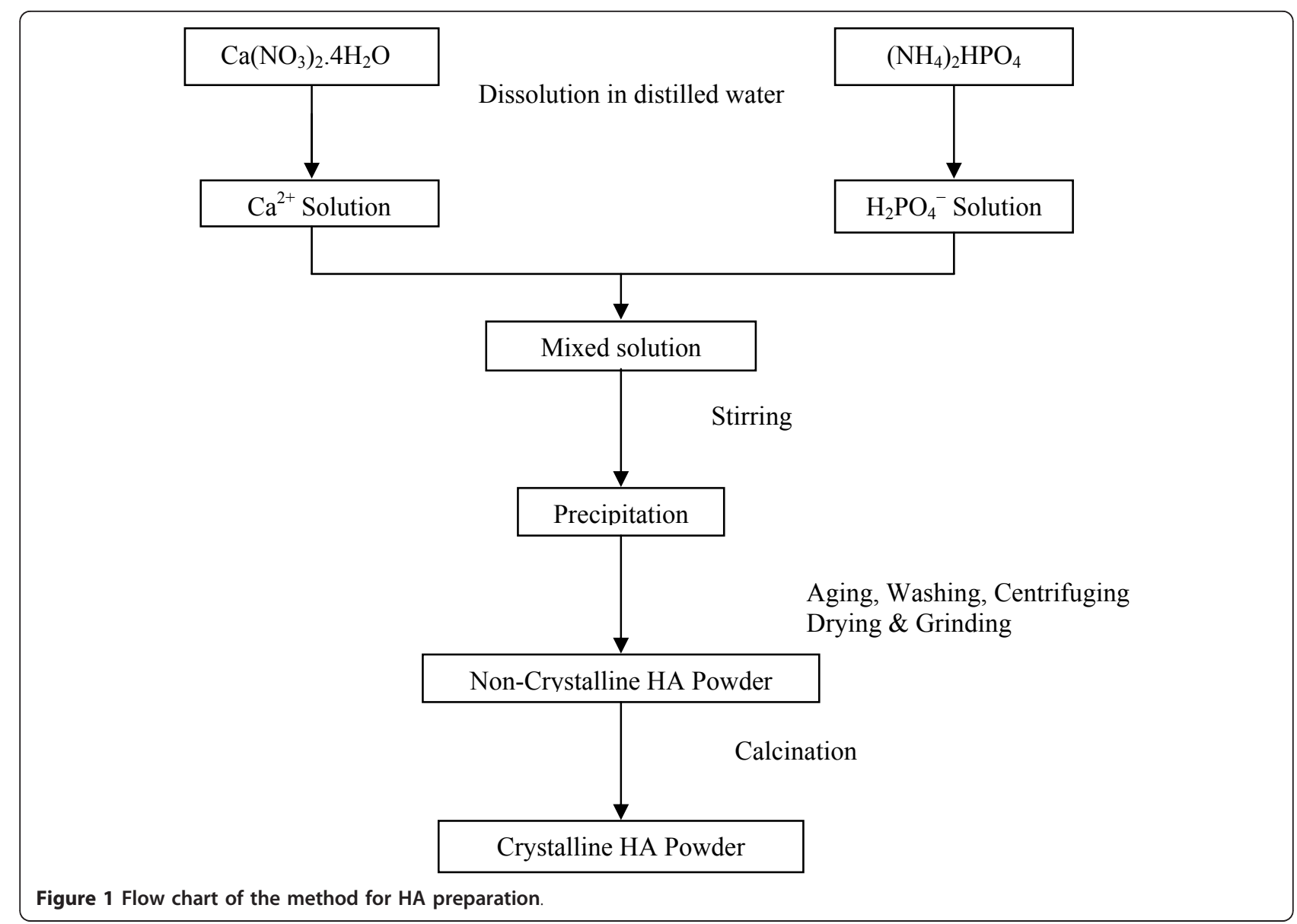

the XRF results, except for the Si-HA sample, as shown in Table 4, where a decease in the silicon percentage is recorded in the value measured by ICP: $1.2 \mathrm{wt} \%$. Whereas, no noticeable change is detected in the $\mathrm{Ca} / \mathrm{P}$ molar ratios measured by either XRF or ICP.

\section{Main crystalline phases determined by XRD}

$\mathrm{X}$-ray diffraction patterns of both; green and heat-treated $\mathrm{HA}_{\mathrm{s}}$ and ion-substituted HA powders are shown in Figures 2 and 3 . The ions substitution does not appear to affect the diffraction pattern of hydroxyapatite, the patterns of the all materials appear to be identical, matching the ICDD standard for HA (JCPDS 09-432). After heating

Table 2 Chemical constitution of green powders, showing the calculated and measured molar ratios

\begin{tabular}{llll}
\hline Sample symbol & Calculated & Measured & Measured (wt\%) \\
\cline { 2 - 4 } & $\mathrm{Ca} /(\mathbf{P}+\mathrm{Si})$ & $\mathrm{Ca} /(\mathbf{P}+\mathrm{Si})$ & $\mathrm{Si}$ \\
\hline $\mathrm{HA} \mathrm{s}_{\mathrm{S}}$ & - & - & - \\
\hline $\mathrm{Si}-\mathrm{HA}$ & 1.13 & 1.397 & 4.0 \\
\hline $\mathrm{Si}-\mathrm{CHA}$ & 1.78 & 1.376 & 0.523 \\
\hline
\end{tabular}

at $900^{\circ} \mathrm{C}$ for $1 \mathrm{~h}$ (Figure 3) these patterns show that the peaks are sharper than those of green samples, pointing out a higher degree of crystallinity. Furthermore, the patterns show no secondary phases, such as TCP or $\mathrm{CaO}$, except for the $\mathrm{Si}-\mathrm{CHA}$ that showed some peaks corresponding to $\beta$-TCP (Figure $3 \mathrm{~b}$ ).

The average crystallite size of the samples is calculated using the Scherrer formula [18], as shown in Table 5. Both types of the silicon-substituted hydroxyapatites have small crystallite size as compared to $\mathrm{HA}_{\mathrm{s}}$. Moreover, the size is even smaller in silicon substituted HA (Si-HA) than the one containing carbonate, Si-CHA.

The effect of ion substitution on the crystal structure of hydroxyapatite was determined by detecting a variation in the lattice parameters. The lattice parameters (a and c) were determined through the (hkl) peaks positions of apatites from XRD patterns according to the following formula $[19,20]$ :

$$
1 / d^{2}=4 / 3\left(h^{2}+h k+l^{2}\right) / a^{2}+l^{2} / c^{2}
$$

$\mathrm{d}$ is the lattice distance obtained from XRD results are shown in Table 5 . 
Table 3 Chemical constitution of green powders, showing the calculated and measured Si concentration in wt\%

\begin{tabular}{lllll}
\hline Sample symbol & Calculated $\mathbf{X}_{\mathbf{S i}}$ & Measured $\mathbf{X}_{\mathbf{S i}}$ & Calculated Ca/P & Measured Ca/P \\
\hline $\mathrm{HA}_{\mathrm{s}}$ & - & - & 1.67 & 1.68 \\
\hline $\mathrm{Si}-\mathrm{HA}$ & 0.5128 & 0.314 & 1.71 & 1.83 \\
\hline $\mathrm{Si}-\mathrm{CHA}$ & 0.0609 & 0.03214 & 1.88 & 1.42 \\
\hline
\end{tabular}

All samples with silicon or/and carbonate substitution showed a decrease in the a-axis and an increase in the $\mathrm{c}$-axis of the unit cell of hydroxyapatite.

\section{Main constituting groups of prepared powders determined by FTIR}

The spectra of the green apatite powders (Figure 4) showed the typical absorption bands related to the modes of phosphate: ( $v_{2}$ bending, $\sim 471 \mathrm{~cm}^{-1} ; v_{4}$ bending, $\sim 565 \mathrm{~cm}^{-1}$ and $\sim 603 \mathrm{~cm}^{-1} ; v_{1}$ symmetric, stretch, $\sim 962 \mathrm{~cm}^{-1} ; v_{3}$ asymmetric, stretching, around $\sim 1033$ $1067 \mathrm{~cm}^{-1}$, hydroxyl (stretching, $\sim 350 \mathrm{~cm}^{-1}$; Vibrational mode, $632 \mathrm{~cm}^{-1}$ ), but, the intensity and resolution are less in the different substituted hydroxyapatite than the standard one. Additionally the bands corresponding to carbonate in B position ( $v_{2}$ bending, $\sim 875 \mathrm{~cm}^{-1} ; v_{3}$ stretching, $\left.\sim 1384,1420,1455 \mathrm{~cm}^{-1}\right)$ are detected in all the spectra of the green powders. IR spectra indicate the deficiency of carbonation in the hydroxyl site, (A-carbonation) as evident from the shoulder band at $\sim 1540 \mathrm{~cm}$ ${ }^{-1}$ in $\mathrm{HA}_{\mathrm{s}}$ and $\mathrm{Si}-\mathrm{HA}$ powders. This band is absent in $\mathrm{Si}-\mathrm{CHA}$, therefore, these powders are considered to be mainly B-carbonated types.

Adsorbed water bands are located in the region around ( 3000-3440 $\left.\mathrm{cm}^{-1}\right)$ [21] and occluded water band at $\sim 1640 \mathrm{~cm}^{-1}$ [22] in all the spectra.

Moreover, two additional IR bands are detected in the IR spectra of Si-HA (with higher Si percent) at $\sim 822 \mathrm{~cm}$ -1 , and $\sim 800 \mathrm{~cm}^{-1}$, respectively. The latter band appearing at $800 \mathrm{~cm}^{-1}$ is assigned to $\mathrm{Si}-\mathrm{O}-\mathrm{Si}$ vibration modes of $\left(\mathrm{SiO}_{4}\right)^{4-}$ groups which have been polymerized as previously reported [23].

The FTIR spectra of heat-treated samples showed several significant changes from the corresponding green ones (see Figure 5). The broad band due to moisture in the sample disappeared and the $\mathrm{OH}$ band in heat-treated samples appeared as a very sharp peak. The clear peaks corresponding to carbonate (B-and A-type) in the FTIR spectra of the green samples, become less

Table 4 Difference in composition of Si-HA as measured by ICP

\begin{tabular}{llll}
\hline $\begin{array}{l}\text { Sample } \\
\text { symbol }\end{array}$ & $\begin{array}{l}\text { measured } \\
\mathrm{X}_{\mathrm{Si}}\end{array}$ & $\begin{array}{l}\text { Measured Ca/(P } \\
+\mathrm{Si})\end{array}$ & $\begin{array}{l}\text { Measured (wt } \\
\%) \\
\mathrm{Si}\end{array}$ \\
\hline $\mathrm{Si}-\mathrm{HA}$ & 0.0947 & 1.667 & 1.2 \\
\hline
\end{tabular}

intense in all the heat-treated samples, especially in that obtained in absence of added carbonate; $\mathrm{HA}_{\mathrm{s}}$ and $\mathrm{Si}$ $\mathrm{HA}$. The band assigned to $\mathrm{SiO}_{4}{ }^{4-}$ (polymerized) modes at $800 \mathrm{~cm}^{-1}$ in $\mathrm{Si}$-HA becomes more intense than in the green. Additionally, new two bands are observed in the spectra of $\mathrm{Si}-\mathrm{CHA}$ at $502 \mathrm{~cm}^{-1}$ and $892 \mathrm{~cm}^{-1}$, these were previously observed by Sprio et al. [24] in the hydroxyapatite containing silicon. These bands are absent in the $\mathrm{HA}_{\mathrm{s}}$ sample. They might be attributed to modifications of the apatite structure induced by the presence of silicon.

\section{Activity of prepared powders in SBF}

Results of $\mathrm{pH}$ measurements for disc samples immersed for different time durations in SBF solutions are shown in Figures 6 and 7. $\mathrm{pH}$ of the control SBF solution remained stable all over the periods of testing.

All green discs of the different hydroxyapatites showed slightly alkaline effect on $\mathrm{pH}$ between 7.1 to 7.4 but less than the SBF over the periods of immersion. The heattreated samples on the other hand, showed relatively alkaline effect on $\mathrm{pH}$ of SBF. A variation in $\mathrm{pH}$ is recorded demonstrated by alternatively decreasing and increasing throughout the different durations, but always above the control SBF pH for Si-CHA sample.

Figures 8, 9, 10, 11, 12, 13, 14 and 15 show calcium $\left(\mathrm{Ca}^{2+}\right)$, phosphorus $\left(\mathrm{P}^{5+}\right)$, sodium $\left(\mathrm{Na}^{+}\right)$, and silicon $\left(\mathrm{Si}^{4}\right.$ $\left.{ }^{+}\right)$ion concentrations in the SBF solution after the different immersion periods for both the green and the heat-treated samples, of the various synthesized apatite samples. Green samples showed an uptake of $\mathrm{Ca}^{2+}$ from

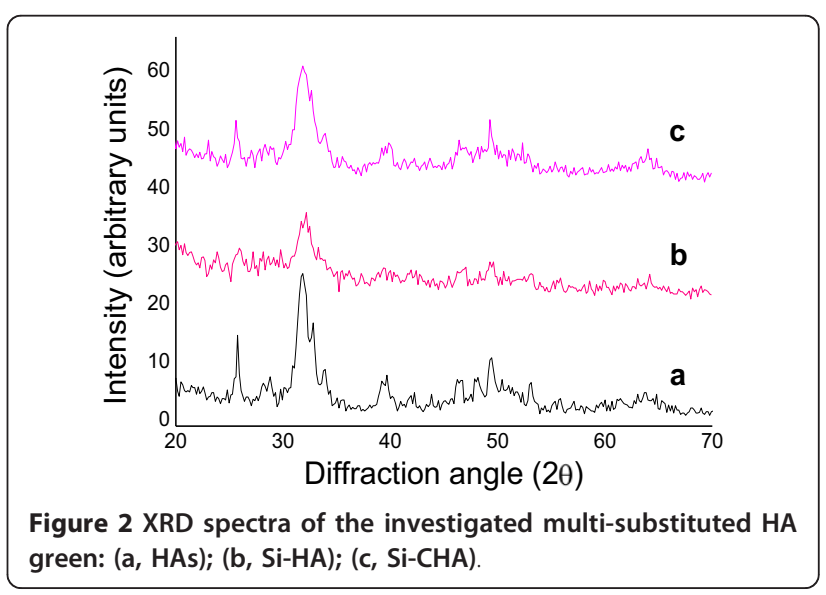



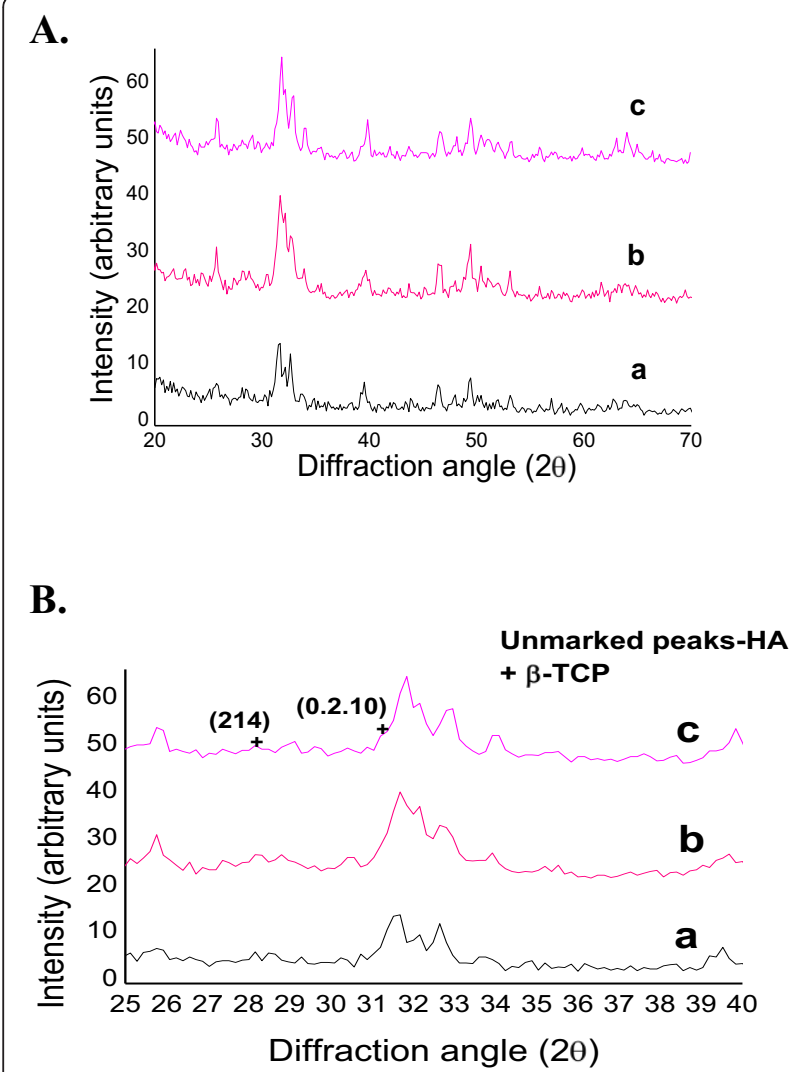

Figure 3 XRD spectra of the investigated multi-substituted HA fired at $900^{\circ} \mathrm{C}: \mathrm{A}$. $\left(\mathrm{a}, \mathrm{HA}_{\mathrm{s}}\right)$; (b, Si-HA); (c, Si-CHA). B. $\left(\mathrm{a}, \mathrm{HA}_{\mathrm{s}}\right)$; (b, $\mathrm{Si}-\mathrm{HA})$; (c, Si-CHA).

the SBF solution during the first soaking period (Figure 8). Least uptake is recorded by Si-CHA. A release of $\mathrm{Ca}^{2+}$ in the latter four periods is recorded by samples, but still below the level of its concentration in the original SBF solution. A similar behaviour is displayed by the heat-treated samples (Figure 9). $\mathrm{HA}_{\mathrm{s}}$ and $\mathrm{Si}$-HA samples showed an uptake of $\mathrm{Ca}^{2+}$ from solution lowering the concentration below that of the original SBF solution. $\mathrm{Si}-\mathrm{CHA}$ on the other hand showed a high release of $\mathrm{Ca}^{2}$ ${ }^{+}$to the SBF solution varying with the period of immersion.

The uptake of P by the different green HA disc samples is relatively high, samples consumed most of the $\mathrm{P}$ supplied by the SBF solution depending on the immersion period. It reaches its optimum after 9 days by all samples when the P of the SBF is consumed, as demonstrated in Figure 10. The fired discs, showed less amount of uptake and gradually increases with the period of immersion as evident from the percentage recorded in the solutions (Figure 11).

Results of green and fired discs of the different hydroxyapatite samples show an uptake of sodium from the solution (Figures 12 and 13). The major uptake is
Table 5 Lattice parameters and the average crystallite size of samples calcined at $900^{\circ} \mathrm{C}$ as calculated from XRD

\begin{tabular}{llll}
\hline $\begin{array}{l}\text { Sample } \\
\text { symbol }\end{array}$ & $\begin{array}{l}\text { a-axis } \\
(\mathbf{n m})\end{array}$ & $\begin{array}{l}\text { c-axis } \\
(\mathbf{n m})\end{array}$ & $\begin{array}{l}\text { Average crystallite size } \\
(\mathbf{n m})\end{array}$ \\
\hline $\mathrm{HA}_{\mathrm{s}}$ & 0.94765 & 0.68461 & 48 \\
\hline $\mathrm{Si}-\mathrm{HA}$ & 0.94269 & 0.68945 & 24 \\
\hline $\mathrm{Si}-\mathrm{CHA}$ & 0.93962 & 0.68618 & 26 \\
\hline
\end{tabular}

displayed by the $\mathrm{HA}_{\mathrm{s}}$ sample. It even consumed most of the sodium ion in the solution after the two last periods 9 and 14 days. All samples nearly consumed the sodium ions from the SBF solution after 5 days.

The silicon substituted hydroxyapatite green and fired disc samples showed a release of silicon ion into the solution of SBF, as shown in Figures 14 and 15. Maximum release is displayed by the $\mathrm{Si}$-CHA sample after the period of 14 days.

SEM of processed green disc samples before and after the immersion in SBF for 14 days are shown in Figure 16. A new layer of nano-sized precipitates agglomerated in clusters is formed. They appear as bright tiny spots. These agglomerates are more frequent and legitimately cover the surface in hydroxyapatite containing silicon and carbonate; $\mathrm{Si}$ - $\mathrm{CHA}$ more than the carbonate free samples $\mathrm{Si}-\mathrm{HA}$ and $\mathrm{HA}_{\mathrm{s}}$. $\mathrm{HA}_{\mathrm{s}}$ sample on the other hand showed sporadic distribution of these agglomerates.

SEM of fired hydroxyapatite discs before and after immersion for 29 days in SBF solution, are shown in Figure 17. All processed discs showed compact surface cut by flaws and pores. The layer developed on the surface appeared as white tiny spots in $\mathrm{HA}_{\mathrm{s}}$, forming a network of bar shaped particles. These bars less evident in $\mathrm{Si}-\mathrm{HA}$ disc, but well developed in Si-CHA sample appearing as more agglomerated tiny prismatic grains, as shown at higher magnification in Figure 18.

EDS analysis is performed on the sample top surface for all the substituted hydroxyapatites, as fired samples. It shows that these precipitates are crystalline materials like

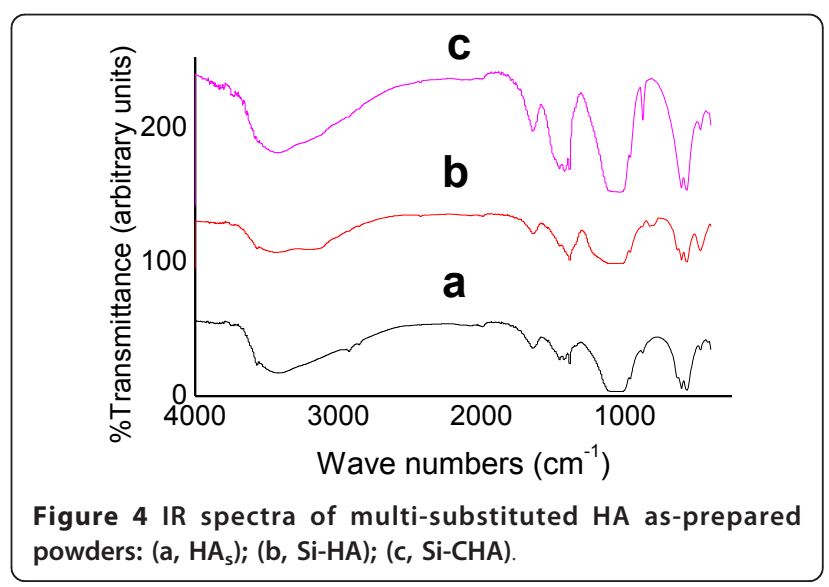




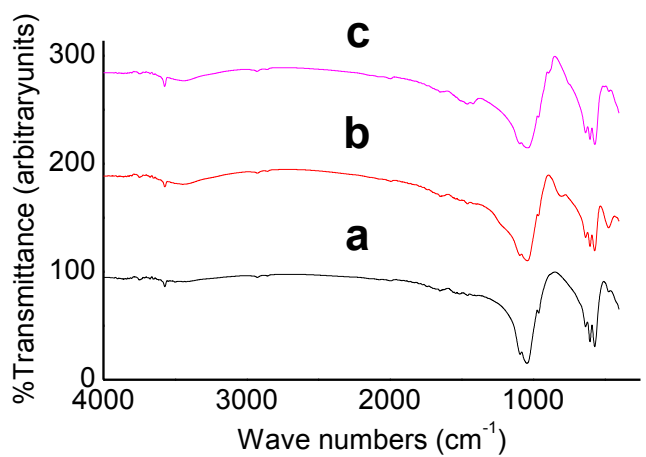

Figure 5 IR spectra of multi-substituted HA powders fired at $900^{\circ} \mathrm{C}:\left(\mathrm{a}, \mathrm{HA}_{\mathrm{s}}\right)$; (b, Si-HA); (c, Si-CHA).

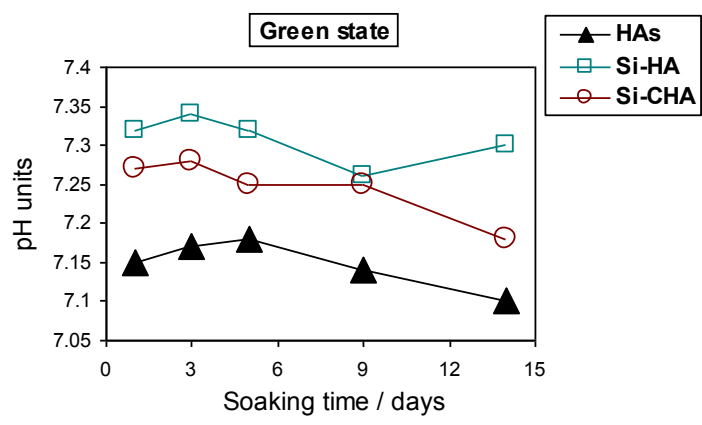

Figure 6 Changes in SBF $\mathrm{pH}$ with time of immersion for the green discs of different hydroxyapatites. $\mathrm{pH}$ of control SBF at $\sim 7.4$.

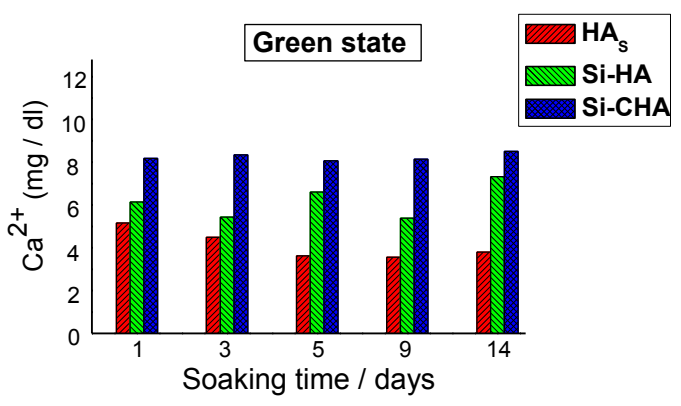

Figure 8 Calcium ion concentration in simulated body fluid of $H A_{s}$ and the two substituted-HA green samples. Calcium ion concentration of SBF: $10 \mathrm{mg} / \mathrm{dl}$.

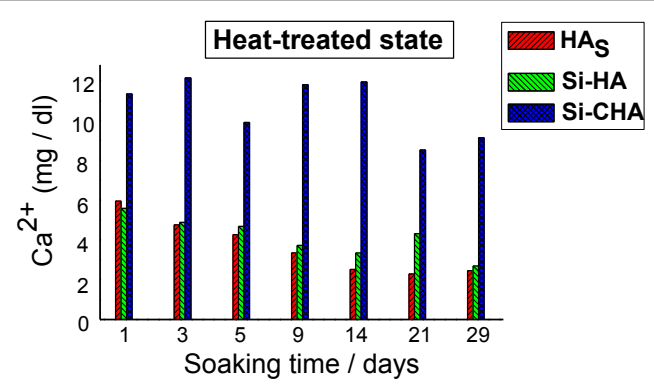

Figure 9 Calcium ion concentration in simulated body fluid of $\mathrm{HA}_{\mathrm{s}}$ and the two substituted-HA heat-treated samples. Calcium ion concentration of SBF: $10 \mathrm{mg} / \mathrm{dl}$.

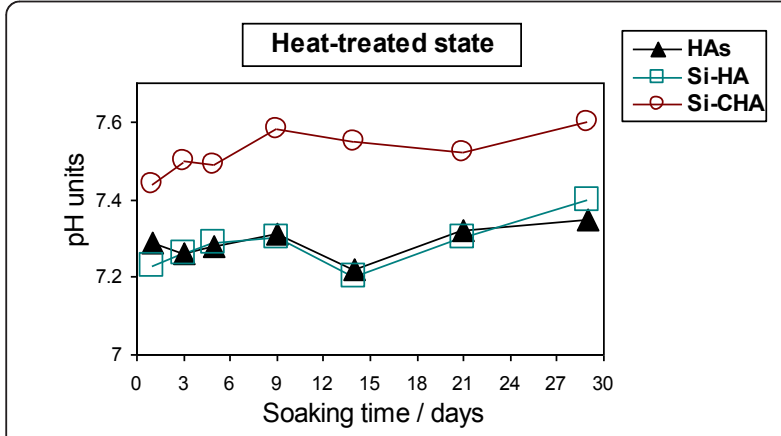

Figure 7 Changes in SBF pH with time of immersion for the fired discs of different hydroxyapatites. $\mathrm{pH}$ of control SBF at $\sim 7.4$.

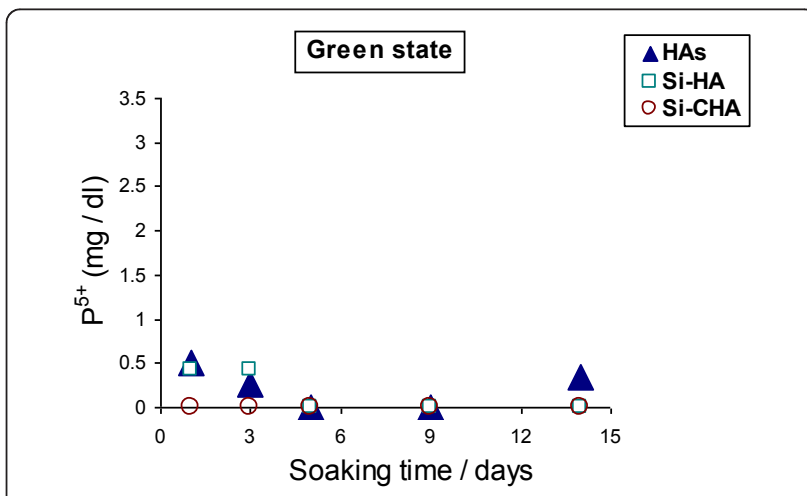

Figure 10 Change in phosphorus ion concentration of SBF solution with immersion period of green discs for different hydroxyapatites. Phosphorus ion concentration of SBF: $4.33 \mathrm{mg} / \mathrm{dl}$. 


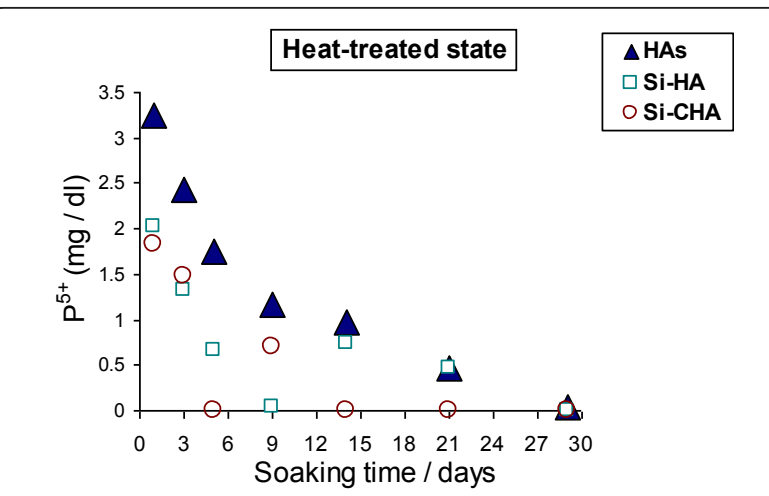

Figure 11 Change in phosphorus ion concentration of SBF solution with immersion period of fired discs for different hydroxyapatites. Phosphorus ion concentration of SBF: $4.33 \mathrm{mg} / \mathrm{dl}$.

the biological apatites, rich in $\mathrm{Ca}, 35.08 \mathrm{wt} \%$ and $\mathrm{P} 21.67$ wt $\%$ and contain amounts of $\mathrm{C}, 35.82 \mathrm{wt} \%, \mathrm{Na}, 0.13 \mathrm{wt} \%$ and $\mathrm{Si}, 7.30 \mathrm{wt} \%$, in the case of $\mathrm{Si}-\mathrm{HA}$ sample, and $\mathrm{Ca}$, 48.34 wt\%, P 24.06 wt\%, C 26.78 wt\%, Na 0.30 wt\% and $\mathrm{Si}, 0.52 \mathrm{wt} \%$, in the case of $\mathrm{Si}-\mathrm{CHA}$ sample. Therefore, the $\mathrm{Ca} / \mathrm{P}$ molar ratios of these newly formed apatites are different from that of the stoichiometric value of HA of 1.67 , by decreasing or increasing due to the substitution of the incorporating ions from SBF such as $\mathrm{Na}$ or $\mathrm{Si} / \mathrm{CO}_{3}$ ions for calcium or phosphate in HA lattice.

\section{Discussion}

In the present work, the calculated molar ratio; $\mathrm{Ca} /(\mathrm{P}$ $+\mathrm{Si}$ ) was $<1.67$ of $\mathrm{Si}-\mathrm{HA}$ powders prepared with excess $\mathrm{Si}$. The content of $\mathrm{P}$ as determined by XRF, represents $91.8 \%$ of $\mathrm{HA}$ and $\mathrm{Si}$ accounts for the $28.45 \%$ rest, (in terms of $\mathrm{X}_{\mathrm{Si}} ; \mathrm{X}_{\mathrm{Si}}$ which is about $60.25 \%$ of the initial value). The recorded reduction in $\mathrm{P}$ and $\mathrm{Si}$ concentrations, was compensated by the introduction of the carbonate that was detected by FTIR, as it occupies the $\left(\mathrm{PO}_{4}{ }^{3-}\right)$ sites in the HA lattice. The amount of Si measured by XRF and ICP was 4.0 and 1.2 wt\%, respectively.

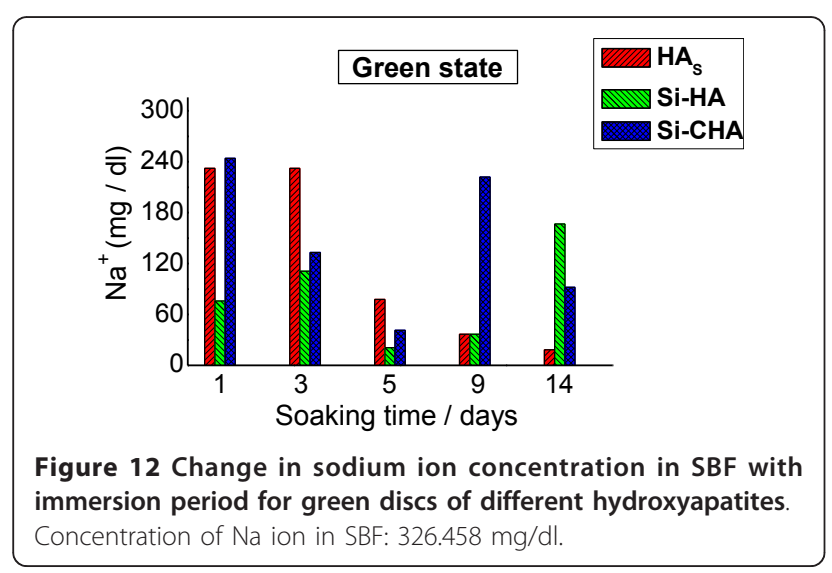

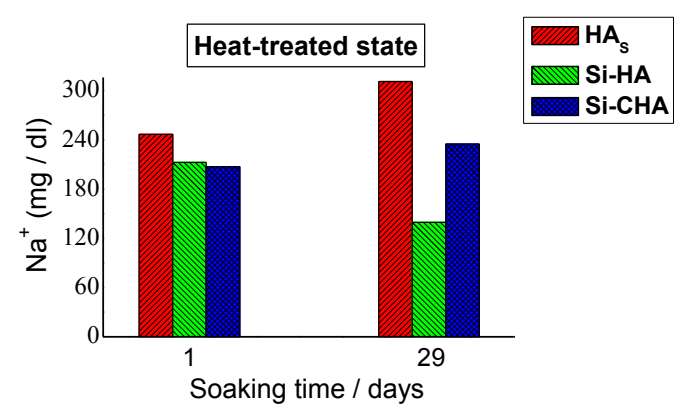

Figure 13 Change in sodium ion concentration in SBF with immersion period for fired discs of different hydroxyapatites. Concentration of $\mathrm{Na}$ ion in SBF: $326.458 \mathrm{mg} / \mathrm{dl}$.

This indicates that not all the added silica $4.0 \mathrm{wt} \%$ entered in the HA lattice. Only the percent determined by ICP as a result of the dissolution of the prepared powder with the $\mathrm{Si}$ encountered in the lattice. The rest silica was transformed into polymerized silica that was amorphous not identified by XRD and not easily dissolute. Therefore, the main Si-O-Si bands corresponding to silica are identified by FTIR.

The reason for this polymerization is the competition between $\left(\mathrm{CO}_{3}{ }^{2-}\right)$ and $\left(\mathrm{SiO}_{4}{ }^{4-}\right)$ to substitute for the $\left(\mathrm{PO}_{4}{ }^{3-}\right)$ groups in HA structure. The charge difference resulting from the substitution of $\left(\mathrm{SiO}_{4}{ }^{4-}\right)$ for $\left(\mathrm{PO}_{4}{ }^{3-}\right)$ in $\mathrm{HA}$, is compensated by loss of $\mathrm{OH}^{-}$, which is limited by the number of $\mathrm{OH}$ ions that can be extracted from the HA structure.

The excess silicate species that failed to substitute into HA lattice, polymerized on the surface of the prepared HA grains. This amorphous phase affects the sharpness of the XRD peaks becoming wider and less intense. This polymerization is ensured by the appearance of the new band at $800 \mathrm{~cm}^{-1}$ corresponding to the Si-O-Si stretching modes. Balas et al. [25] and Tang et al. [26] detect the polymerization behavior. Balas et al. [25] reported that an increase of the silicon content up to $1.6 \mathrm{wt} \%$ leads to the polymerization of the silicate species at the surface, that is readily

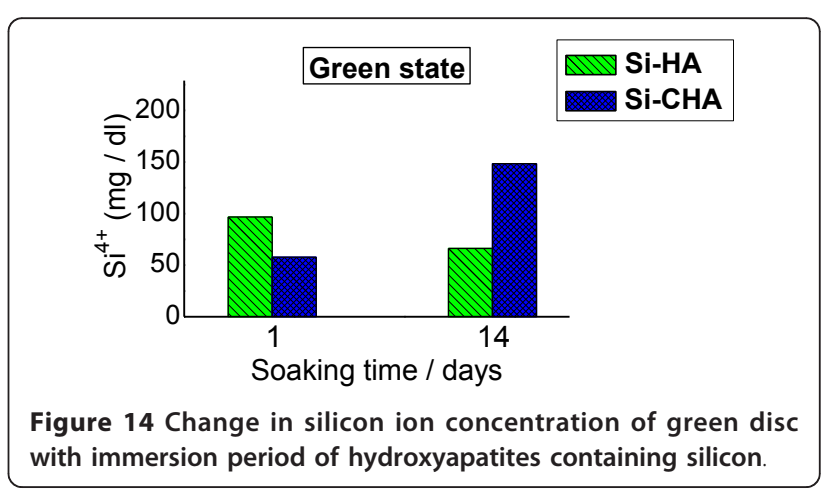




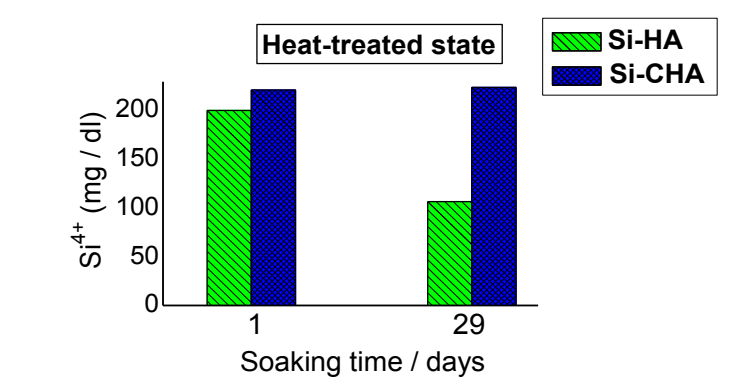

Figure 15 Change in silicon ion concentration of fired disc with immersion period of hydroxyapatites containing silicon.

recorded for $1.5 \mathrm{wt} \%$ by Tang et al. [26] They explained the phenomenon as the charge difference between $\left(\mathrm{SiO}_{4}{ }^{4-}\right)$ and $\left(\mathrm{PO}_{4}{ }^{3-}\right)$ compensated by the introduction of $\left(\mathrm{CO}_{3}{ }^{2-}\right)$ beside the silicate in the lattice. Yet, the $\left(\mathrm{CO}_{3}{ }^{2-}\right)$ is preferred to the silicate in the lattice. Moreover the substitution of $\left(\mathrm{SiO}_{4}{ }^{4-}\right)$ for $\left(\mathrm{PO}_{4}{ }^{3}\right.$ $\left.{ }^{-}\right)$in HA charge is compensated by loss of $\mathrm{OH}^{-}$ extracted from the structure. So when the TEOS content increases the silicate species that could not incorporate in the lattice polymerize on the HA surface. This cause the XRD peaks to widen becoming less intense.

No other phosphate or silicate phases are recorded in the XRD pattern of Si-HA. The incorporation of silicon into the HA was previously explained by Gibson et al. [27] Silicon atoms substitute for $P$ in the center of the tetrahedron with the four $\mathrm{O}$ atoms at the corners. The radius of $\mathrm{Si}^{4+}$ is greater than that of $\mathrm{P}^{5+}$, and the average length of the $\mathrm{Si}-\mathrm{O}$ bonds $(0.162 \mathrm{~nm})$ is greater than that of the P-O bonds $(0.152 \mathrm{~nm}$, Boyer et al. [28]). The radius of the $\left(\mathrm{PO}_{4}\right)$ tetrahedron would be expected to be smaller than that of the $\left(\mathrm{SiO}_{4}\right)$ tetrahedron, which results in a change of HA lattice constants, as was explained by Balas et al. [25] and Tang et al. [26].

The recorded change in lattice parameters determined through the (hkl) peaks positions of apatites from XRD is a decrease in the a-axis and an increase in the c-axis of the unit cell of HA.

However, the present results showed the incorporation of $\mathrm{CO}_{3}$ in the lattice of the prepared Si-HA. According

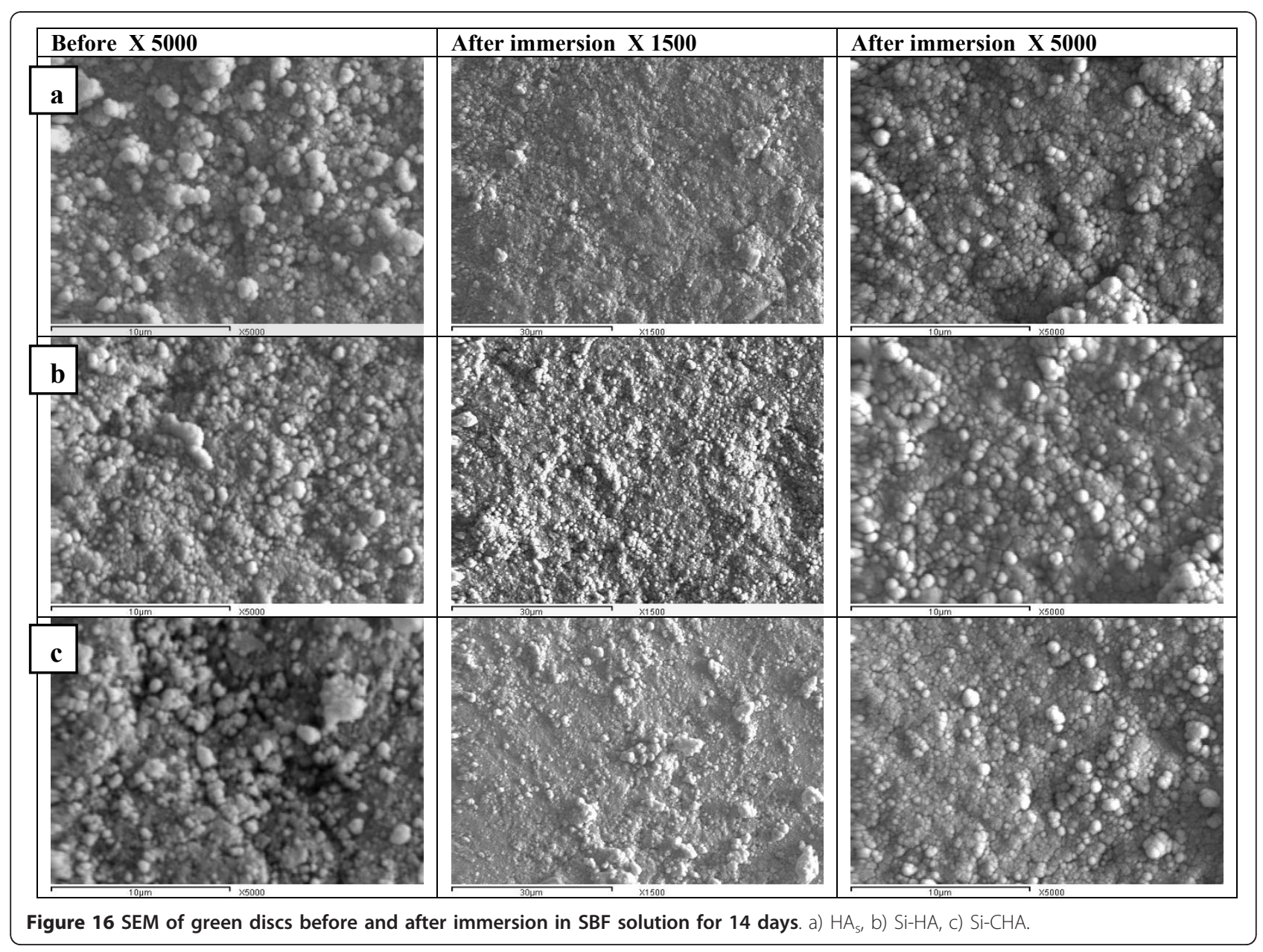




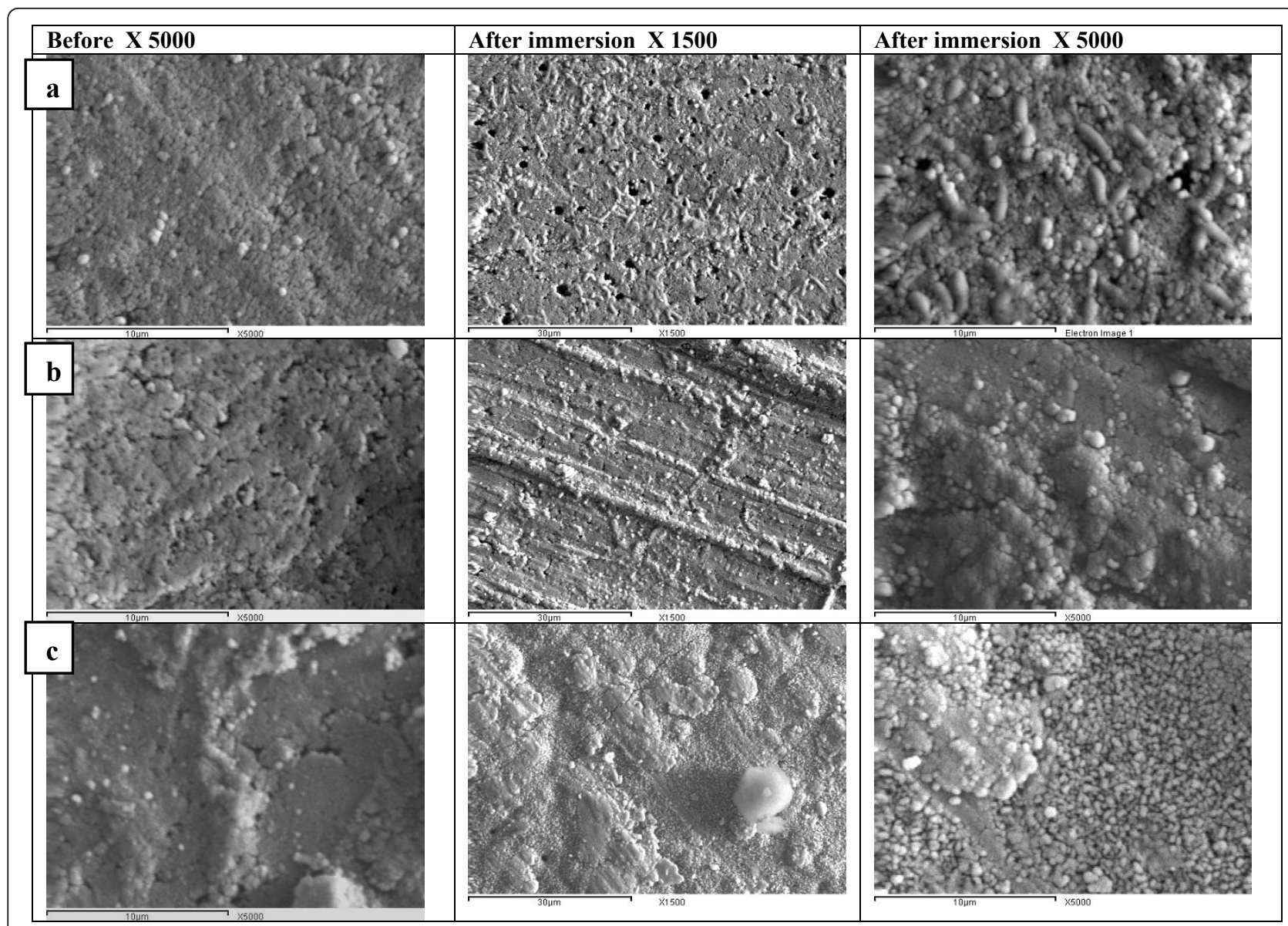

Figure 17 SEM of fired discs before and after immersion in SBF solution for 29 days. a) $H A_{s}$, b) Si-HA, c) Si-CHA.

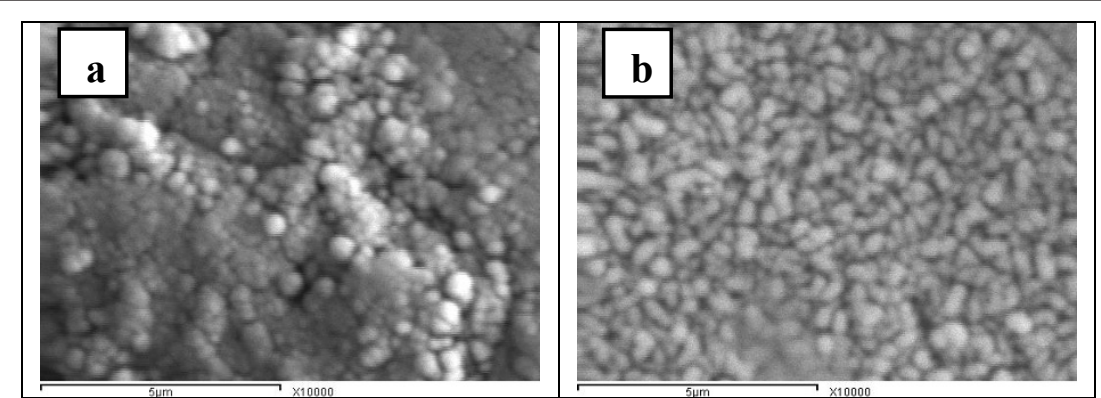

Figure 18 SEM of fired hydroxyapatite disc samples after immersion in SBF for 29 days. a) Si-HA, b) Si-CHA, with higher magnification, $\times$ 10000 .

to Tang et al. [26] the TEOS furnishes the $\mathrm{CO}_{3}$, as its content increases with the proportion added according to the following mechanism:

$$
\begin{gathered}
\mathrm{Si}\left(\mathrm{OCH}_{2} \mathrm{CH}_{3}\right)+4 \mathrm{H}_{2} \mathrm{O}------\mathrm{Si}(\mathrm{OH})_{4}+4 \mathrm{CH}_{3} \mathrm{CH}_{2} \mathrm{OH} \\
\mathrm{nSi}(\mathrm{OH})_{4}------\left(\mathrm{SiO}_{2}\right)_{\mathrm{n}}+2 \mathrm{H}_{2} \mathrm{O} \\
\mathrm{CH}_{3} \mathrm{CH}_{2} \mathrm{OH}+4 \mathrm{O}_{2}-------2 \mathrm{CO}_{2}+3 \mathrm{H}_{2} \mathrm{O}
\end{gathered}
$$

The XRD patterns obtained in the present study shows the peaks broader and less intense compared with pure HA attributed to the ill-crystalline nature of the product, accompanying the formation of hydroxyl vacancies, caused by the isomorphous substitution of $\left(\mathrm{PO}_{4}{ }^{3-}\right)$ by $\left(\mathrm{SiO}_{4}{ }^{4-}\right)$. 
The multi-substituted HA samples ( $\mathrm{Si}-\mathrm{CHA}$ ) showed high solubility for silicon ion, over that of the sample containing silicon, in spite of the low substituting amount of silicon in them, $0.523 \mathrm{wt} \%$ for $\mathrm{Si}-\mathrm{CHA}$, as compared to $4.0 \mathrm{wt} \%$ for Si-HA.

The immersion of the apatite disks in SBF solution produces noticeable changes in the chemical composition of the solution. Balas et al. [25] reported a rapid decrease in calcium ion at the beginning of the reaction that reaches a quasi-stationary state after 3 weeks. The hydroxyapatite which does not contain silicon shows the lower activity in trapping calcium from the solution. The calcium consumption by the samples is proportional to the decrease of the $\mathrm{pH}$. On the other hand, no significant change in the phosphorus concentration is observed in the first two weeks, but it began to increase after 3 weeks, indicating dissolution of the surface layer. Phosphorus remains essentially in equilibrium with the solid in the first two weeks with no remarkable change.

The change in the chemical composition of the solution could be understood on the basis of proton/calcium exchange between the $\mathrm{P}-\mathrm{OH}$ groups present at the apatite surface and the $\mathrm{Ca}^{2+}$ ions of the solution.

$$
2 \mathrm{PO}-\mathrm{H}+\mathrm{Ca}^{2+}---------(\mathrm{PO})_{2} \mathrm{Ca}+2 \mathrm{H}^{+}
$$

The decrease of $\mathrm{pH}$ produced by this reaction would enhance the solubility of the apatite, which increases with the $\mathrm{H}^{+}$ion concentration, indicating dissolution of the surface layer. Sprio et al. [24] reported a release of calcium ions with a rate more than doubled when granules of HA powders containing carbonate (Si-CHA compared to the carbonate-free $\mathrm{HA}$, or ( $\mathrm{Si}-\mathrm{HA})$.

The case reported by Balas et al. [25] is similar to what happened in the present work. The application of disc specimens furnish less surface to the action of SBF solution compared with the granulated powders tested by Sprio et al. [24] that subjects a high surface area to solution. Meanwhile the surface of the discs forms a center for the nucleation of the calcium phosphate layer providing the needed ions from the SBF solution. As a result a drop in both $\mathrm{Ca}^{2+}$ and $\mathrm{p}^{5+}$ ion concentrations of the SBF solution, in the first two periods followed by a dissolution of the surface layer.

The EDS of the precipitated calcium phosphate layer on the surface showed the incorporation of $\mathrm{Na}$ and $\mathrm{C}$ from the solution beside the $\mathrm{Ca}$ and $\mathrm{P}$, and that was confirmed through the analysis of SBF for $\mathrm{Na}$ ion, a result was not recorded before. This confirms the fact that wherever $\mathrm{Na}$ ion is available in the solution it is incorporated beside the other substituted ions.

\section{Conclusions}

The present study succeeded in the preparation of synthetic multi-substituted hydroxyapatite nano powders; namely, $\mathrm{Si}-\mathrm{HA}$ and $\mathrm{Si}-\mathrm{CHA}$, by using the wet chemical method. The chemical analysis confirmed the presence of the substituting atoms in the final HA powders. No secondary phases are found to contaminate the substituted HA, except for that containing initial amount of carbonate ions, Si-CHA, where $\beta$-TCP formed.

The ion substitution in the crystal lattice of HA caused a change in the unit cell dimensions and affected the degree of crystallization of the produced powders.

The activity as measured by immersion in SBF solution was higher for the prepared powders over the un-substituted HA. The HA that with simultaneous occupation of the phosphate site by silicate and carbonate ions, exhibit the highest solubility and a faster release, compared with carbonate-free powder.

All prepared powders took sodium ion from the SBF solution during immersion which was not recorded before.

\section{Author details}

${ }^{1}$ Ceramics Department, National Research Centre, 12622 Dokki, Cairo, Egypt. 2Biomaterials Department, National Research Centre, 12622 Dokki, Cairo, Egypt. ${ }^{3}$ Advanced materials and nanotechnology lab., National Research Centre, 12622 Dokki, Cairo, Egypt.

\section{Authors' contributions}

SK carried out the practical works and drafted the manuscript. AM participated in the sequence alignment, carried out the chemical constitution assays and drafted the manuscript. DM conceived and participated in the design of the study. All authors read and approved the final manuscript.

\section{Competing interests}

The authors declare that they have no competing interests.

Received: 21 October 2011 Accepted: 28 November 2011 Published: 28 November 2011

\section{References}

1. Suchanek W, Yoshimura M: Processing and properties of hydroxyapatitebased biomaterials for use as hard tissue replacement implants. J Mate Res 1998, 13:94-117.

2. Bigi A, Cojazzi G, Panzavolta S, Ripamonti A, Roveri N, Romanello M, Noris Suarez K, Moro L: Chemical and structural characterization of the mineral phase from cortical and trabecular bone. J Inorg Biochem 1997, 68:45-51.

3. Driessens FCM: The mineral in bone, dentin and tooth enamel. Bull SoC Chim Belg 1997, 89:663-689.

4. Smith DK: Calcium Phosphate Apatites in Nature. In Hydroxyapatite and Related Materials. Edited by: Brown PW, Constantz B. Boca Raton, FL: CRC Press; 1994:29-45.

5. Carlisle EM: Silicon: a possible factor in bone calcification. Science 1969, 167:279-80.

6. Ruys AJ: Silicon-doped hydroxyapatite. J Aust Ceram Soc 1993, 29:71-80.

7. Rey C, Collins B, Goehl T, Dickson IR, Glimcher M: The carbonate environment in bone mineral: a resolution-enhanced Fourier Transform Infrared Spectroscopy Study. Calcif Tissue Int 1989, 45:157-64.

8. LeGeros RZ: Calcium Phosphates in Oral Biology and Medicine. In Monographs in Oral Sciences. Edited by: Myers Karger H. Basel: AG Publishers; 1991:82 
9. Carlisle EM: In vivo requirement for silicon in articular cartilage and connective tissue formation in the chick. J Nutr 1976, 106:478-484.

10. Carlisle EM: Silicon: a requirement in bone formation independent of vitamin D1. Calcif Tissue Int 1981, 33:27-34.

11. Carlisle EM: A silicon requirement for normal skull formation in chicks. J Nutr 1980, 110:352-359.

12. Gibson IR, Huang J, Best SM, Bonfield W: Enhanced in Vitro Cell Activity and Surface Apatite Layer Formation on Novel Silicon-Substituted Hydroxyapatites. In Proceedings of the 12th International Symposium on Ceramics in Medicine, Nara, Japan Edited by: Ohgushi H, Hasting GW, Yoshikawa T 1999, 191-194.

13. Patel N, Gibson IR, Hing KA, Best SM, Damien E, Revell PA Bonfield W: The In Vivo Response of Phase Pure Hydroxyapatite and Carbonate Substituted Hydroxyapatite Granules of Varying Size Ranges. In Proceedings of the 14th International Symposium on Ceramics in Medicine. Edited by: Brown S, Clarke I, Williams P. Palm Springs, California, USA: 2001:282-286.

14. Porter AE, Patel N, Skepper JN, Best SM, Bonfield W: Effect of sintered silicate-substituted hydroxyapatite on remodelling processes at the bone-implant interfac. Biomaterials 2004, 25:3303-3314.

15. Porter AE, Patel N, Skepper JN, Best SM, Bonfield W: Comparison of in vivo dissolution processes in hydroxyapatite and Si-substituted hydroxyapatite bioceramics. Biomaterials 2003, 24:4609-4620.

16. Jarcho M, Bolen CH, Thomas MB, Bobick J, Kay JF, Doremus RH: Synthesis and characterization in dense polycrystalline form. J Mater Sci 1976, 11:2027-2035.

17. Kokubo T: Bioactive Glass Ceramics: Properties and Applications. Biomaterials 1991, 12:155-163.

18. Bouyer E, Gitzhofer F, Boulos I: Morphological study of hydroxyapatite nanocrystal suspension. J Mater Sci Mater Med 2000, 11:523-531.

19. Hammond C: The Basics of Crystallography and Diffraction New York: Oxford University Press; 2002, 416.

20. Koutsopoulos S: Synthesis and Characterization of Hydroxyapatite Crystals: A Review Study on the Analytical Methods. J Biomed Mater Res 2002, 62:600-612.

21. Suchanek WL, Shuk P, Byrappa K, Rimana RE, TenHuisen KS, Janas VF: Mechanochemical-hydrothermal synthesis of carbonated apatite powders at room temperature. Biomaterials 2002, 23:699-710.

22. Tadic D, Peters F, Epple M: Continuous Synthesis of Amorphous Carbonated Apatites. Biomaterials 2002, 23:2553-2559.

23. Fidalgo A, liharco LM: The defect structure of sol-gel-derived silica/ polytetrahydrofuran hybrid films by FTIR. J Non-Cryst Solids 2001, 283:144-154.

24. Sprio S, Tampieri A, Landi E, Sandri M, Martorana S, Celotti G, Logroscino G: Physico-chemical properties and solubility behaviour of multisubstituted hydroxyapatite powders containing silicon. Mater Sci Eng 2008, 28:179-187.

25. Balas F, Pérez-Pariente J, Vallet-Regí M: in Vitro bioactivity of siliconsubstituted hydroxyapatites. J Biomed Mater Res 2003, 66:364-375.

26. Tang XL, Xiao XF, Liu RF: Structural characterization of silicon-substituted hydroxyapatite synthesized by a hydrothermal method. Materials Letters 2005, 59:3841-3864.

27. Gibson IR, Best SM, Bonfield W: Chemical characterization of siliconsubstituted hydroxyapatite. J Biomed Mater Res 1999, 44:422-428.

28. Boyer L, Carpena J, Lacout JL: Synthesis of phosphate-silicate apatites at atmospheric pressure. Solid Stat lon 1997, 95:121-129.

doi:10.1186/1752-153X-5-74

Cite this article as: Ibrahim et al:: Chemical characterization of some substituted hydroxyapatites. Chemistry Central Journal 2011 5:74.

\section{Publish with ChemistryCentral and every scientist can read your work free of charge \\ "Open access provides opportunities to our colleagues in other parts of the globe, by allowing anyone to view the content free of charge." \\ W. Jeffery Hurst, The Hershey Company. \\ - available free of charge to the entire scientific community \\ - peer reviewed and published immediately upon acceptance \\ - cited in PubMed and archived on PubMed Central \\ - yours - you keep the copyright \\ Submit your manuscript here: \\ http://www.chemistrycentral.com/manuscript/<smiles>c1ccccc1</smiles> ChemistryCentral}

